\title{
ANALISIS PENGARUH LINGKUNGAN KERJA FISIK DAN NONFISIK, TERHADAP PRODUKTIVITAS PEGAWAI PADA UNIVERSITAS ISLAM DARUL ULUM LAMONGAN
}

\author{
Ahmad Fathur Rozi \\ Unversitas Islam Darul Ulum Lamongan \\ fathurrozi@unisda.ac.id \\ Ahmad Yani Syaikhudin \\ Unversitas Islam Darul Ulum Lamongan \\ ahyani@unisda.ac.id
}

\begin{abstract}
In organizations or human resources, companies are assets that are considered very potential and important. One that makes employees comfortable is the physical and nonphysical environment. From this problem can increase productivity. Human resources in this case employees or employees of organizations or companies should not be underestimated. Organizations or companies must provide a special section that is tasked with handling problems relating to employees, that part is called human resource management (HR) or more commonly called the personnel section. Personnel in this case are human resource managers. The manager's scope includes learning and developing ways for employees to effectively devote all their potential and strengths to help achieve the goals of the organization or company.

This study uses a quantitative descriptive approach and this study has a population of 260 respondents and a sample of 80 respondents. The data obtained were analyzed through validity test, reliability test, multiple regression analysis, and hypothesis testing with $T$ test, and analysis of the coefficient of determination (R2).

This study has physical work environment variables (X1), coloring indicators, cleanliness, lighting, air, spatial planning, and non-physical work environment variables (X2) indicators are supervision, work atmosphere, reward system, good treatment, security of members, and employee productivity variables $(Y)$ the indicators are human, capital, production process, organizational environment, work environment.

From the results of the regression analysis it is known that the greatest influence on employee productivity is the non-physical work environment (X2) which has a coefficient of 0.698. Then the next variable is the physical work environment (X1) with a coefficient of 0.203. Hypothesis testing Then from the results of the T test showed that the two independent variables proved to have a significant effect on employee work productivity. In addition, the adjusted $R$ square determination coefficient test of 0.689 shows that $68.9 \%$ of variation in employee productivity can be explained by two independent variables in the regression equation. While the remaining $31.1 \%$ is explained by other variables beyond the two variables used in this study.
\end{abstract}

Keywords: Physical Work Environment, Non-Physical Work Environment, Employee Productivity. 


\begin{abstract}
ABSTRAK
Dalam organisasi atau sumber daya manusia, perusahaan adalah aset yang dianggap sangat potensial dan penting. Salah satu yang membuat karyawan nyaman adalah lingkungan fisik dan non-fisik. Dari masalah ini dapat meningkatkan produktivitas. Sumber daya manusia dalam hal ini karyawan atau karyawan organisasi atau perusahaan tidak boleh diremehkan. Organisasi atau perusahaan harus menyediakan bagian khusus yang bertugas menangani masalah yang berkaitan dengan karyawan, bagian itu disebut manajemen sumber daya manusia (SDM) atau yang lebih umum disebut bagian personalia. Personil dalam hal ini adalah manajer sumber daya manusia. Ruang lingkup manajer meliputi pembelajaran dan pengembangan cara bagi karyawan untuk secara efektif mencurahkan semua potensi dan kekuatan mereka untuk membantu mencapai tujuan organisasi atau perusahaan.

Penelitian ini menggunakan pendekatan deskriptif kuantitatif dan penelitian ini memiliki populasi 260 responden dan sampel 80 responden. Data yang diperoleh dianalisis melalui uji validitas, uji reliabilitas, analisis regresi berganda, dan pengujian hipotesis dengan uji T, serta analisis koefisien determinasi $(R 2)$.

Penelitian ini memiliki variabel lingkungan kerja fisik (X1), indikator pewarnaan, kebersihan, pencahayaan, udara, perencanaan tata ruang, dan variabel lingkungan kerja non fisik (X2) indikatornya adalah pengawasan, suasana kerja, sistem penghargaan, perlakuan yang baik, keamanan anggota, dan variabel produktivitas karyawan $(Y)$ indikatornya adalah manusia, modal, proses produksi, lingkungan organisasi, lingkungan kerja.

Dari hasil analisis regresi diketahui bahwa pengaruh terbesar terhadap produktivitas karyawan adalah lingkungan kerja non fisik (X2) yang memiliki koefisien 0,698. Kemudian variabel berikutnya adalah lingkungan kerja fisik (X1) dengan koefisien 0,203. Pengujian hipotesis Kemudian dari hasil uji T menunjukkan bahwa kedua variabel independen terbukti berpengaruh signifikan terhadap produktivitas kerja karyawan. Selain itu, uji koefisien determinasi $R$ square yang disesuaikan sebesar 0,689 menunjukkan bahwa 68,9\% variasi dalam produktivitas karyawan dapat dijelaskan oleh dua variabel independen dalam persamaan regresi. Sedangkan sisanya 31,1\% dijelaskan oleh variabel lain di luar dua variabel yang digunakan dalam penelitian ini.
\end{abstract}

Kata kunci: Lingkungan Kerja Fisik, Lingkungan Kerja Non Fisik, Produktivitas Karyawan.

\title{
PENDAHULUAN
}

\section{Latar Belakang}

Salah satu sumber daya yang terdapat dalam organisasi atau perusahaan ialah sumber daya manusia. Sumberdaya manusia merupakan sumberdaya yang memiliki banyak kelebihan di banding sumber daya lain yang ada pada organisasi atau perusahaan. Sumber daya manusia memiliki akal, pikiran, perasaan, keinginan, kemampuan, keterampilan, pengetahuan, daya, dorongan, karya, inovasi, kreasi dan harapan.

Kelebihan sumber daya manusia menjadi sebuah potensi yang positif. Potensipotensi yang dimiliki sumber daya manusia mempengaruhi upaya organisasi atau perusahaan dalam mencapai tujuan. Tanpa sumberdaya manusia organisasi atau perusahaan tidak ada artinya, teknologi maju, informasi baru dan lengkap, modal 
banyak, bahan baku berlimpah, sarana dan prasarana lengkap itu sia-sia tanpa adanya sumber daya manusia yang menjalankannya.

Dalam organisasi atau perusahaan sumber daya manusia adalah asset yang dianggap sangat potensial dan penting. Sumber daya manusia dalam hal ini pegawai atau karyawan pada organisasi atau perusahaan tidak boleh dipandang sebelah mata. Organisasi atau perusahaan harus menyediakan bagian khusus yang bertugas mengurusi masalah-masalah yang berhubungan dengan karyawan, bagian itu disebut manajemen sumber daya manusia (MSDM) atau lebih sering disebut bagian personalia. Pesonalia timbul karena adanya tuntutan untuk menyelesaikan masalah yang berhubungan dengan karyawan. Personalia dalam hal ini manajer sumber daya manusia. Ruang lingkup manajer meliputi mempelajari dan mengembangkan cara agar karyawan secara efektif mencurahkan semua potensi dan kekuatan untuk membantu mencapai tujuan organisasi atau perusahaan.

Banyak terdapat karyawan pada suatu organisasi atau perusahaan yang memiliki kepribadian, kemampuan, nilai-nilai, kebutuhan, harapan dan keinginan yang berbedabeda, hal ini menimbulkan bentuk reaksi, hasrat, pola piker, dan tingkah laku yang berbeda. Perbedaan yang timbul pada masing-masing individu karyawan menuntut seorang manajer mampu mengintegrasikan, mengkomunikasikan, mengarahkan, mengkombinasikan dan menyelaraskan semua perbedaan yang ada agar menjadi kekuatan dan potensi hebat guna membantu dan mempermudah dalam menciptakan strategi mencapai tujuan organisasi atau perusahaan.

Manajer yang baik dapat memelihara prestasi, meningkatkan produktivitas, meningkatkan kinerja, menambah semangat untuk melaksanakan tugas mereka sesuai aturan dan pengarahan. Motivasi yang berhasil diberikan kepada karyawan dapat member pencapaian kebutuhan dan mengurangi ketidak seimbangan.

Karyawan menginginkan suatu iklim kerja yang menyenangkan dalam hal ini iklim kerja meliputi ruang kerja yang aman dan nyaman, rekan rekan kerja yang menyenangkan untuk bekerja sama dalam pekerjaan, pemimpin yang bijaksana dan adil, fasilitas saranadan prasarana fisik yang baik, kebijakan dan peraturan yang baik dan tepat, imbalan jasa uang dan non uang yang layak dan adil, jenis pekerjaan yang sesuai dan yang berkualitas serta tantangan kerja yang menarik. 
Selain faktor motivasi yang berasal dari diri individu karyawan, ada juga faktor motivasi yang berasal dari organisasi atau perusahaan dan manajer yang berupa gaji dan lingkungan kerja. Semua motivasi tersebut harus bersama-sama sejalan dan seirama agar tujuan organisasi atau perusahaan dan karyawan sama-sama mudah tercapai.

Masalah yang sering dihadapi seorang pemimpin organisasi atau perusahaan yaitu bagaimana cara menciptakan lingkungan kerja yang baik, sehingga dapat meningkatkan produktivitas kerja karyawan.

\section{LANDASAN TEORI}

\section{Lingkungan Kerja}

Lingkungan Kerja adalah segala yang ada di sekitar para pekerja yang dapat mempengaruhi dirinya dalam menjalankan tugas yang dibebankan. Nitisemito, (2011 : 183). Pendapat lain mengatakan lingkungan kerja adalah keadaan fisik dimana seseorang melakukan tugas kewajibannya sehari-hari termasuk kondisi ruang yaitu baik dari kantor maupun pabrik ( Siagian, 2011 : 139)

Rofiq Ahmad (2011 : 104) mengatakan selain lingkungan kerja fisik perlu juga diperhatikan lingkungan kerja non fisik atau psikologis. Setelah mengetahui pendapatpendapat tersebut di atas maka dapat ditarik suatu pengertian bahwa lingkungan kerja merupakan keadaan dimana seseorang bekerja yang meliputi perlengkapan dan fasilitas, suasana kerja (lingkungan non fisik) maupun lingkungan fisik yang dapat mempengaruhi pekrja dalam melaksanakan tugas dan tanggung jawabnya.

Terdapat bermacam-macam faktor yang mempengaruhi lingkungan kerja dimana kegiatan dilaksanakan, yaitu:

1. Perlengkapan dan fasilitas

2. Suasana kerja (non physical working environment)

3. Lingkungan tempat kerja (physical working environment)

Menurut Sedarmayanti (2001:31) lingkungan kerja non fisik adalah semua keadaan yang terjadi yang berkaitan dengan hubungan kerja, baik dengan atasan maupun dengan sesama rekan kerja, ataupun dengan bawahan.

\section{Lingkungan Kerja Fisik}

Hubungan antara lingkungan fisik dengan kenyamanan kerja sangat signifikan. Perasaan nyaman berpusat di hati setiap orang, lingkungan fisik kantor akan 
bersentuhan langsung dengan tubuh kita, melalui media panca indera tersebut kemudian mengalir kedalam hati sehingga lingkungan fisik kantor yang baik akan menimbulkan perasaan nyaman. Misalnya seseorang akan merasa nyaman dalam bekerja karena lingkungan kerjanya tertata rapi dan bersih, warna- warna cat dinding atau peralatan kantor serasi, dan penerangan kantor yang memadai.

Menurut Sedarmayanti (2006) "lingkungan kerja fisik adalah semua yang terdapat disekitar tempat kerja yang dapat mempengaruhi pegawai baik secara langsung maupun tidak langsung"

Lingkungan kerja fisik mempengaruhi semangat dan emosi kerja para karyawan. Faktor-faktor fisik ini mencakup suhu udara di tempat kerja, luas ruang kerja, kebisingan, kepadatan, dan kesesakan.

Berdasarkan definisi tersebut dapat dinyatakan lingkungan kerja fisik adalah segala sesuatu yang ada disekitar karyawan bekerja yang mempengaruhi karyawan dalam melaksanakan beban tugasnya. Masalah lingkungan kerja dalam suatu organisasi sangatlah penting, dalam hal ini diperlukan adanya pengaturan maupun penataan.

Adapun Indikator lingkungan kerja fisik adalah sebagai berikut :

1. Pewarnaan.

Masalah pewarnaan ini bukan hanya pewarnaan dinding saja, tetapi sangat luas, sehingga dapat juga pewarnaan mesin-mesin, peralatan, bahkan pewarnaan dari seragam yang mereka pakai perlu mendapat perhatian. Dengan memakai warna yang tepat pada dinding ruangan dan alat-alat lainnya, kegembiraan dan ketenangan bekerja para pegawai akan terpelihara. Selain itu warna yang tepat akan mencegah kesilauan yang mungkin timbul karena cahaya yan berlebihan (The Liang Gie, 2006)

Komposisi warna yang salah dapat pula mengganggu pemandangan. Sehingga dapat menimbulkan rasa tidak atau kurang menyenangkan bagi mereka yang memandang. Dan rasa tidak menyenangkan ini dapat mempengaruhi semangat dan kegairahan kerja para pegawai. Penggunaan warna yang baik akan memberikan keuntungan sebagai berikut:

- Memungkinkan kantor menjadi tempat yang menyenangkan dan menarik

- Mempunyai akibat yang tidak langsung terhadap produktivitas pegawai. 


\section{Kebersihan.}

Kebersihan merupakan syarat pertama untuk pegawai-pegawai yang sehat dan pelaksanaannya tidak akan memerlukan banyak ongkos. Dalam setiap urusan hendaknya selalu menjaga kebersihan lingkungan, sebab selain mempengaruhi kesehatan juga akan mempengaruhi kesehatan jiwa seseorang. Lingkungan kerja yang bersih bisa menimbulkan rasa senang, dan rasa senang ini akan dapat mempengaruhi seseorang untuk bekerja lebih bersemangat dan lebih bergairah lagi.

Kebersihan kantor mencakup kebersihan bangunan, perlengkapan dan perabotan. Karena menurut The Liang Gie (2006:363) istilah perabot berupa meja, kursi, lemari merupakan bagian dari perlengkapan, maka uraian mengenai perabot dimasukkan ke dalam kebersihan perlengkapan.

\section{Penerangan}

Penerangan di dalam lingkungan kerja maksudnya adalah cukupnya sinar yang masuk ke dalam ruang kerja masing-masing pegawai kantor. Dengan tingkat penerangan yang cukup di dalam ruang kerja, akan mendorong pegawai untk bekerja lebih baik. Dengan demikian pelaksanaan dan hasil kerja yang diperoleh pegawai akan menjadi lebih baik. Penerangan yang tidak memadai akan mengakibatkan para pegawai tidak jelas melihat dan mengamati pekerjaan yang dilaksanakannya. Dalam hal ini akan memperbesar tingkat kesalahan para pegawai tersebut.

Penerangan atau cahaya yang cukup merupakan pertimbangan yang paling penting dalam fasilitas fisik kantor. Keuntungan yang dapat diperoleh sehubungan dengan dilaksanakannya penerangan yang baik bagi kantor adalah :

a) Adanya perbaikan kualitas pekerjaan para pegawai

b) Adanya kenaikan tingkat produksi

c) Berkurangnya tingkat kecelakaan

d) Terdapatnya kemudahan pengamatan dan pengawasan

e) Peningkatan gairah kerja pegawai

f) Kerusakan barang dalam proses berkurang

g) Biaya produksi akan tertekan. 


\section{Udara}

Pengaturan udara yang baik akan dapat menyebabkan kesegaran fisik pegawai. Sebaliknya pertukaran udara yang kurang akan dapat menimbulkan rasa pengap sehingga mudah menimbulkan kelelahan dari para pegawai.

5. Tata Ruang.

Merumuskan Tata ruang adalah menyusunan atau pengaturan perkakas dan peralatan dalam ruang lantai yang tersedia,

Tujuan tata ruang kerja adalah : aliran pekerjaan yang efektif, ruang yang luas akan tetapi dipergunakan dengan baik, kesenangan dan rasa puas para pekerja, memudahkan pengawasan, kesan yang baik bagi para pelanggan dan tamu, dan fleksibilitas yang besar untuk kebutuhan-kebutuhan yang berlainan.

\section{Lingkungan kerja non fisik}

Menurut Sedarmayanti (2001), "Lingkungan kerja non fisik adalah semua keadaan yang terjadi yang berkaitan dengan hubungan kerja, baik hubungan dengan atasan maupun hubungan sesama rekan kerja, ataupun hubungan dengan bawahan”.

Berdasarkan pengertian tersebut, dapat dikatakan bahwa lingkungan kerja non fisik disebut juga lingkungan kerja psikis, yaitu keadaan di sekitar tempat kerja yang bersifat non fisik Lingkungan kerja semacam ini tidak dapat ditangkap secara langsung dengan pancaindera manusia, namun dapat dirasakan keberadaannya. Jadi, lingkungan kerja non fisik merupakan lingkungan kerja yang hanya dapat dirasakan oleh perasaan.

Dari pendapat dan uraian tersebut, maka dapat dikatakan bahwa lingkungan kerja non fisik adalah lingkungan kerja yang tidak dapat ditangkap dengan panca indera manusia. Akan tetapi, lingkungan kerja non fisik ini dapat dirasakan oleh para pekerja melalui hubungan-hubungan sesama pekerja maupun dengan atasan.

Sikap yang diharapkan tentunya adalah sikap positif yang mendukung terhadap pelaksanaan kerja yang dapat menjamin pencapaian tujuan organisasi. Sehubungan dengan masalah pembentukan dan pengusahan sikap, bahwa unsur penting dalam pembentukan dan pengubahan sikap dan perilaku, yaitu adalah sebagai berikut.

1. Suasana kerja yang dapat memberikan dorongan dan semangat kerja yang tinggi.

2. Sistem pemberian imbalan (baik gaji maupun perangsang lain) yang menarik. 
3. Perlakuan dengan baik, manusiawi, tidak disamakan dengan robot atau mesin, kesempatan untuk mengembangkan karier semaksimal mungkin sesuai dengan batas kemampuan masing-masing anggota.

4. Ada rasa aman dari para anggota, baik di dalam dinas maupun di luar dinas.

.Menurut Nitisemito (2006) perusahan hendaknya dapat mencerminkan kondisi yang mendukung kerja sama antara tingkat atasan, bawahan maupun yang memiliki status jabatan yang sama diperusahaan. Kondisi yang hendaknya diciptakan adalah suasana kekeluargaan, komunikasi yang baik dan pengendalian diri. Membina hubungan yang baik antara sesama rekan kerja, bawahan maupun atasan harus dilakukan karena kita saling membutuhkan. Hubungan kerja yang terbentuk sangat mempengaruhi psikologis karyawan.

\section{a. Produktivitas Pegawai}

Produktifitas kerja memiliki makna filosofis, definisi, Menurut Prof. Dr. Sofjan Assauri $(2008 ; 31)$ secara definisi kerja produktifitas merupakan perbandingan antara hasil yang dicapai (keluaran) dengan sumberdaya (pemasukan) yang dipergunakan persatuan waktu. Secara filosofi produktifitas merupakan pandangan hidup dan sikap mental yang selalu berusaha meningkatkan mutu kehidupan "hari ini harus lebih baik dari kemarin, dan besok harus lebih baik dari hari ini". Pandangan seperti itu membantu manusia selalu ingin berkembang dan tidak mudah merasa puas.

Faktor manusia merupakan salah satu faktor produksi bagi karyawan yang memegang peranan penting dalam kegiatan proses produksi, kerena didasari peralatan lainnya. Serta teknologi yang pada hekekatnya hanya merupakan karya manusia. Sedangkan faktor-faktor produksi lainnya dapat dikendalikan oleh tenaga manusia.

Pada organisasi perusahaan yang bergerak di bidang industri barang dan jasa peranan sumber daya manusia selalu dituntut agar dapat bekerja secara lebih efektif dan efisien guna menghasilkan produk berupa barang dan jasa. Untuk menghilangkan hambatan yang ada juga meningkatkan output yang dihasilkan, maka seorang manajer perlu memperhatikan :

a) Kualitas kerja yang meliputi ketelitian, ketepatan, ketrampilan dan kebersihan.

b) Kualitas kerja yang meliputi jumlah output, baik itu output rutin maupun output ekstra. 
c) Ketepatan waktu, apakah dalam pekerjaan itu telah sesuai dengan waktu standart yang telah ditentukan lebih cepat atau malah labih lambat.

d) Dapat diandalkan, bahwa orang-orang tersebut memang benarbenar mampu untuk mengerjakan tugas tersebut dan produknya dapat diandalkan baik jumlah maupun mutunya.

e) Sasaran, bahwa apa yang telah dikerjakan telah sesuai dengan sasaran.

Sehingga dapat dikemukakan bahwa produktivitas adalah ukuran efisiensi dengan mana modal, material, teknologi, manajemen sumber daya manusia dan informasi yang digunakan dengan tujuan memproduksi barang dan jasa secara ekonomis. Sumber daya manusia memegang peranan utama dalam proses peningkatan produktivitas, karena peralatan produksi, tekhnologi serta sistem manajemen pada hakekatnya adalah hasil karya manusia.

a. Pengukuran Tingkat Produktivitas

Pengukuran tingkat produktivitas merupakan suatu alat manajemen yang penting di semua tingkatan ekonomi karena dapat digunakan untuk membantu mengevaluasi pelaksanaan dari suatu perencanaan perkembangan kegiatan dari suatu periode ke periode berikutnya.

Untuk mengatahui tinggi rendahnya produktivitas maka diperlukan cara pengukuran yang menurut Dharma, ada tiga cara pengukuran, yaitu:

1) Kuantitas, yaitu jumlah yang harus dihasilkan.

2) Kualitas, yaitu mutu yang dihasilkan.

3) Ketepatan waktu sesuai tidaknya dengan waktu yang ditentukan.

Tujuan pengukuran produktivitas kerja karyawan adalah untuk mengoptimalkan faktor-faktor penunjang produktivitas, dan meminimkan faktor-faktor yang menghambat. Oleh Karena itu pengukuran produktivitas di tingkat perusahaan harus dikaitkan dengan perusahaan aktual yang ada di industri maupun ekonomi secara Umum Ukuran produktivitas adalah keluaran per unit dari tenaga kerja.

b. Faktor- Faktor yang mempengaruhi Produktivitas

Faktor-faktor yang mempengaruhi produktivitas terutama di negara berkembang menurut Garry dessler (2006:213), adalah sebagai berikut : 
1. Manusia.

Manusia dipandang sebagai sumber daya manusia dapat di bagi menjadi beberapa bagian, yaitu :
a) Kuantitas.
b) Tingkat keahlian.
c) Struktur pekerjaan.
d) Sikap.
e) Minat.
f) Kemampuan.

2. Proses Produksi

Tata ruang kerja, penanganan bahan baku, penanganan mesin, perencanaan dan pengawasan produksi, pemeliharaan melalui pencegahan, Teknologi, Kuantitas, kualitas, ruangan produksi, struktur organisasi dan spesialisasi produksi.

3. Lingkungan organisasi dan Kerja.

Organisasi dan perencanaan, sistem manajemen, kondisi kerja, iklim kerja, tujuan perusahaan yang berhubungan dengan kelestarian perusahaan.

\section{METODE PENELITIAN}

\section{Jenis Penelitian}

Dalam penelitian ini dilakukan dengan mengambil sampel dari suatu populasi dengan menggunakan kuesioner sebagai alat pengumpulan data yang pokok dan menjelaskan hubungan antara variabel-variabel melalui pengujian hipotesis.

\section{Lokasi Penelitian}

Adapun objek penelitian yang penulis ambil pada Universitas Islam Darul ulum Lamongan

\section{Teknik Sampling}

Teknik sampling merupakan teknik pengambilan sampel (Sugiono, 2015:116), dalam penelitian ini diambil sampel, yang dianggap representatif, teknik yang digunakan dalam penelitian ini adalah teknik random sampling. 


\section{Sumber Data}

1. Data primer

Data yang diperoleh dari lembaga pendidikan Universitas Islam Darul ulum Lamongan dengan cara wawancara langsung dengan pihak Pimpinan dan pegawai

2. Data sekunder

Data yang diperoleh dari dokumen tertulis, buku dan literatur yang berhubungan dengan obyek penelitian.

\section{Analisis Data}

1. Teknik Pengujian Hipotesa (r)

Digunakan untuk mencari ada tidaknya hubungan antara variabel Bebas Lingkungan Kerja Fisik $\left(\mathrm{x}^{\mathbf{1}}\right)$ dan Non Fisik $\left(\mathrm{x}^{\mathbf{2}}\right)$ dengan variabel terikat Produktivitas Pegawai (y).

2. Koefiien derteminant $\left(\mathrm{r}^{2}\right)$

Untuk mengetahui besarnya kontribusi variabel bebas signifikan terhadap variabel terikat (y) atau sebaliknya.

3. Uji t (Uji Signifikansi)

Pengujian hipotesis menggunakan uji t dengan maksud untuk mengetahui apakah variabel bebas (x) secara individu mempunyai hubungan yang signifikan terhadap variabel terikat $(y)$

\section{PEMBAHASAN}

Dalam penelitian ini penulis mencoba untuk memberikan gambaran pada Universitas Islam Darul ulum Lamongan. Universitas Islam Darul ulum Lamongan adalah lembaga yang bergerak dalam dunia pendidikan mempunyai kualitas yang unggul dan sangat baik dalam pengelolaan sumber daya Manusia, khususnya mahasiswa, Karyawan tenaga pendidik

Dari sini Penulis mencoba untuk memberikan gambaran pencapaian Analisis data yang bertujuan untuk memperoleh data karakteristik responden Pegawai atau karyawan di Universitas Islam Darul ulum Lamongan 
Dalam bagian ini akan dijabarkan tentang item-item variabel yang terdiri dari lingkungan kerja fisik (X1), lingkungan kerja non fisik (X2), serta akan juga dijabarkan variabel produktivitas pegawai (Y).

Responden berdasarkan jenis kelamin dideskripsikan untuk membedakan sifat dan kemampuan antara laki-laki dan perempuan, misalnya perempuan dianggap lebih ekspresif, lebih emosional, kurang logis, kurang terorientasi dan lebih partisipatif daripada laki-laki.

Tabel 1

Responden Menurut Jenis Kelamin

\begin{tabular}{|c|c|c|}
\hline Jenis Kelamin & Frekuensi & Prosentase \\
\hline Laki-Laki & 40 & $50 \%$ \\
\hline Perempuan & 40 & $50 \%$ \\
\hline Total & 80 & $100 \%$ \\
\hline
\end{tabular}

Sumber: Data primer yang diolah, 2019

Adapun skor penilaian yang ditetapkan untuk menguraikan dalam indikator produktivitas pegawai Universitas islam darul ulum lamongan adalah seperti yang tercantumpada label 2 sebagai berikut:

Tabel 2

Skor Penilaian Lingkungan Kerja Fisik dan Non Fisik

\begin{tabular}{|c|c|}
\hline Keterangan & Nilai \\
\hline Sangat Setuju & $80-90$ \\
Setuju & $60-79$ \\
Ragu-Ragu & $40-59$ \\
Tidak Setuju & $20-39$ \\
Sangat Tidak Setuju & $0-19$ \\
\hline
\end{tabular}

Data yang diperoleh dari penelitian ini perlu dianalisa lebih lanjut sehingga dapat diketahui hasilnya guna memecahkan permsalahan yang ada. Sedangkan analisa data ini dilakukan dengan menggunakan teknik statistik

Tabel 3.

Koefisien Determinasi

\begin{tabular}{|c|c|c|c|c|}
\hline Model & $\mathrm{R}$ & $\mathrm{R}$ Square & Adjusted R Square & Std. Error of the Estimate \\
\hline 1 & $.840^{\mathrm{a}}$ &, 705 &, 689 &, 503 \\
\hline
\end{tabular}

a. Predictors: (Constant), Lingkungan kerja non fisik, Lingkungan kerja fisik

b. Dependent Variable: produktivitas pegawai 
Menurut Sugiono (2015:231) Kuatnya pengaruh variabel bebas terhadap Variabel terikat berada pada tingkat kuat.

Berdasarkan pengelolaan Data Koefesiensi Kolerasi Dengan hasil perhitungan sebesar $\mathrm{R}=0.840$. Angka pada $\mathrm{R}$ dalam tabel koefisien diterminasi adalah angka yang menunjukan kuatnya hubungan antara variabel lingkungan kerja fisik (X1), lingkungan kerja non fisik (X2), dan Variabel produktivitas pegawai (Y).

Sedangkan Berdasarkan pengelolaan Data Koefesiensi Kolerasi Dengan hasil perhitungan adalah $=0.840$, maka dapat di katagorikan bahwa pengaruh yang di berikan variabel lingkungan kerja fisik dan lingkungan kerja non fisik dalam meningkatkan produktivitas pegawai atau karyawan adalah mempunyai pengaruh yang kuat. Selain itu, di peroleh koefisien determinasi $\mathrm{R} 2=0.705=70,5 \%$. $\mathrm{R}$ adalah angka yang menunjukan besarnya pengaruh variabel lingkungan kerja fisik (X1), lingkungan kerja non fisik (X2) dengan Variabel produktivitas pegawai (Y). Secara diskriptif, pengaruh variabel $\mathrm{X}$ terhadap Variabel $\mathrm{Y}$ sebesar $70,5 \%$ dan sisanya $29.5 \%$ di pengaruhi oleh faktor-faktor lain di luar pelatihan.

Dari Hasil pengelolaan Menggunakan Statistical Package for the Social Sciences (SPSS) di dapat kan Hasil nilai t-hitung dijelaskan sebagai

Tabel 4

Hasil Uji t

\begin{tabular}{|l|c|c|c|c|c|c|c|}
\hline \multirow{2}{*}{ odel } & \multicolumn{2}{c|}{$\begin{array}{c}\text { Unstandardized } \\
\text { Coefficients }\end{array}$} & $\begin{array}{c}\text { Standardized } \\
\text { Coefficients }\end{array}$ & \multirow{2}{*}{$\mathrm{N}$} & \multicolumn{2}{|c|}{ Collinearity Statistics } \\
\cline { 2 - 6 } & $\mathrm{B}$ & Std. Error & Beta & $\mathrm{t}$ & Sig. & Tolerance & VIF \\
\hline (Constant) &, 823 & 1,336 & &, 616 &, 542 & & \\
Lingkungan kerja fisik &, 203 &, 075 &, 241 & 2,699 &, 010 & 1,000 & 1,000 \\
Lingkungan kerja non fisik &, 698 &, 078 &, 802 & 8,981 &, 000 & 1,000 & 1,000 \\
\hline
\end{tabular}

Dependent Variable: Produktivitas

Variabel elemen ekuitas Lingkungan kerja fisik (X1) nilai t hitung 2,699 < t tabel 1,671 dan nilai $\mathrm{p}=0,052<0,005$. Sedangkan Variabel Lingkungan kerja non fisik (X2) nilai t hitung 8,981 < t tabel 1,671 sehingga ada pengaruh yang signifikan antara kedua variabel tersebut terhadap produktivitas pegawai (Y)

Dari masing-masing kedua variabel bebas tersebut. Variabel Lingkungan kerja non fisik mempunyai pengaruh paling Kuat terhadap produktivitas pegawai (y) yakni sebesar 8,981 sedangkan Lingkungan kerja fisik 2,69 
Berarti adanya peranan yang sangat kuat antara variabel lingkungan kerja fisik dan lingkungan kerja non fisik dengan produktivitas pegawai dapat dikatakan bahwa apabila lingkungan kerja fisik dan non fisik yang di perhatikan terhadap pegawai dilaksanakan secara tepat dan kebutuhan serta kondisi karyawan, maka produktivitas kerja karyawan dapat meningkat sesuai dengan yang diharapkan Lembaga tersebut Dengan ini hipotesa yang penulis ajukan atau kemukakan telah terbukti kebenarannya.

\section{SIMPULAN DAN SARAN}

\section{Simpulan}

Berdasarkan dari hasil penelitian hasil pembahasan yang telah di kemukakan oleh penulis dapat di kemukakan peranan yang kuat antara variabel lingkungan kerja fisik dan lingkungan kerja non fisik dengan produktivitas pegawai sehingga perlu ada perhatian khususnya Lingkungan kerja non fisik karena mempunyai pengaruh paling Kuat terhadap produktivitas pegawai (y) yakni sebesar 8,981 sedangkan Lingkungan kerja fisik 2,69. Maka produktivitas pegawai dapat meningkat sesuai dengan yang diharapkan Lembaga. Dengan ini hipotesa yang penulis ajukan atau kemukakan telah terbukti kebenarannya.

Setelah penulis menganalisa data dengan menggunakan koefisien korelasi meningkatkan lingkungan kerja fisik dan lingkungan kerja non fisik adalah mempunyai pengaruh yang kuat. Selain itu, di peroleh koefisien determinasi $\mathrm{R} 2=0.705=70,5 \%$. $\mathrm{R}$ adalah angka yang menunjukan besarnya pengaruh variabel lingkungan kerja fisik dan lingkungan kerja non fisik (X) dengan Variabel produktivitas pegawai (Y). Secara diskriptif, pengaruh variabel $\mathrm{X}$ terhadap Variabel $\mathrm{Y}$ sebesar $70,5 \%$ dan sisanya $29.5 \%$ di pengaruhi oleh faktor-faktor lain di luar pelatihan.

\section{Saran}

Agar karyawan atau pegawai merasa diperhatika hendaknya Lembaga diharapkan lebih meningkatkan lingkungan kerjanya dengan memperhatikan masalah sikologis tataruang dalam ruang kerja, Ukuran dan situasi ruangan kerja, dan toleransi antar pegawai dalam pekerjaan. Hal ini perlu dilakukan karena dari hasil regresi diketahui variabel lingkungan kerja mempunyai pengaruh positif terhadap semangat kerja pegawai sehingga dapat meningkatkan produktivitas dalam bekerja 


\section{DAFTAR PUSTAKA}

Assauri, Soyjan. 2008. Manajemen Produksi dan Operasi. Jakarta: LPFEUI

Arikunto, Suharsimi. (2016). Prosedur Penelitian Suatu Pendekatan Praktek (edisi revisi VI, cetakan ketigabelas). Jakarta : PT Rineka Citra.

Gary Dessler, 2016, Manajemen Sumber Daya Manusia , Edisi 7, PT. Prenhallindo

Martoyo, Susilo. Manajemen sumber daya manusia Tahun:2006. Penerbit: Yogyakarta Sinungan,

Manullang, M,2011, Manajemen Personalia, Penerbit Ghalia Indonesia Jakarta.

Malayu S.P. Hasibuan 2008: pengetahuan bank secara umum

Malayu Hasibuan S.P. 2011. Manajemen Sumber Daya Manusia,cetakan keenam belas. Jakarta: PT.Bumi Aksara

Nitisemito, Alex S. 2016. Manajemen Personalia. Ghaila Indonesia: Jakarta.

Robbins, Stephen P.(2016).Perilaku Organisasi.Edisi kesepuluh. Jakarta: PT Indeks Kelompok Gramedia

Susilo Martoyo. Judul: Manajemen sumber daya manusia / Yogyakarta Sinungan

Sedarmaynti. 2001. Sumber Daya Manusia dan Produktivitas Kerja. Mandar Maju: Bandung

Surja S. Handoko 2011 langkah meningkatkan karier dan jabatan Penerbitan: Jakarta: Gramedia,

Sugiyono, (2011), Metode Penelitian Bisnis, Bandung: Alfabeta.

Sugiyono, 2012, Metode Penelitian Bisnis, Bandung: Alfabeta.

The Liang Ghe. 2006. Manajemen Sumber Daya Manusia. Universitas Trisakti: Jakarta. 